\title{
Chester Irving Barnard'ın Yönetim Tarihindeki İzleri
}

\author{
Nuray AKAR, Onur DíRLiK ${ }^{1}$
}

\begin{abstract}
Chester Irving Barnard’ın Yönetim Tarihindeki İzleri
Özet

Amaçların etkili ve verimli olarak gerçekleştirilmesi doğrultusunda bir insan grubunda, işbirliği ve koordinasyon sağlamaya yönelik faaliyetlerden oluşan yönetim uygulamaları toplumsal yaşam kadar eskidir. Fakat, yönetim ve örgütlerle ilgili sistematik bilgi topluluğu niteliğini taşıyan yönetim bilimi 20. yüzylın ürünüdür. Oldukça gençgörünen bu bilgi topluluğu bir asırlık gibi sürede hızııca gelişmiş, bilimsel niteliği artmıştır. Yönetim disiplinini oluşturan bu bilgi topluluğuna, var olan bilimsel bilginin birikiminde Barnard'ın yaptığı katkının önemli olduğu herkes tarafından kabul görmüştür. Bu çalışmada da Chester Irving Barnard'ın (1886-1961) ileri sürdüğü düşünceler dâhilinde yönetim bilimine katkısı ve günümüz dünyası için söylediklerinin geçerliliği irdelenecektir.
\end{abstract}

Anahtar Kelimeler: Chester Irving Barnard, Klasik yönetim düşüncesi, Otoritenin kabulü, Kayıtsızlık bölgesi

\author{
Chester Irving Barnard's Traces in Management History
}

\section{Abstract}

Management practices, which consist of activities for cooperation and coordination in a group of people in line with the effective and efficient realization of goals, are as old as social life. However, management science, which is a systematic collection of information about management and organizations, is the product of the 20th century. This knowledge community, which seems quite young, has developed rapidly in a century, and its scientific quality has increased. It has been accepted by everyone that Barnard's contribution to this knowledge community, which constitutes the management discipline, is important in the accumulation of existing scientific knowledge. In this study, Chester Irving Barnard's (1886-1961) contribution to management science and the validity of what he said for today's world will be examined.

Keywords: Chester Irving Barnard, Classical management thought, Acceptance of authority, Zone of indifference

\section{Giriş}

Bilimsel inceleme ve araştırmaların, örgüt içi ve örgütsel ortam koşullarındaki değişme ve gelişmelerin, mevcut bilgilerin yetersiz ve etkisiz kalmasına yol açması nedeniyle yönetim düşüncesinin evriminde örgütsel ve yönetsel devrimin çok büyük etkisi olduğu bilinmektedir. Bu iki önemli etki ile birlikte gelişen, 20. yüzylın başlarına denk gelen yazında klasik yönetim düşüncesi olarak adlandırılan bilimsel yönetim akımı, yönetsel teori ve bürokrasi modelinden meydana gelen ilk dönem, yapılan yoğun eleştiriler ve zaman içerisinde yetersiz kalmasına rağmen kendisinden sonra gelen insan ilişkileri yaklaşımının yapılanmasında temelleri atmış, yönetim disiplininde başlangıç noktası olmuştur. Hatta son yıllarda yapılan tartışmalar göstermektedir ki, bazı klasik dönem düşünürlerinin tespitleri günümüzde yeniden üzerine düşünülmesi gereken fenomenler olarak yeni dünya düzeninde kendini göstermektedir.

Çevrenin belirsizliği ve tahmin edilemez olması, uzmanları bile örgütler için doğru reçeteler verme konusunda zorlamaktadır. Ekonomik olarak hayatta kalma mücadelesi veren örgütler pazarların kaotik doğası, teknoloji ve demografik çeşitlilik gibi durumlarla uğraşmakla yükümlüdür. Bu durum yönetim bilimlerinin öğretilerini hem daha değerli kılmakta hem de zorlaşıırmaktadır. Bu yüzden zaman zaman temel meselelere geri dönmek gerekebilmektedir. Barnard'ın ahlaki ikna, özgünlük, güven ve kişisel sorumluluk arasındaki ayrılmaz bağlantılara ilişkin anlayışı, yirmi birinci yüzyıl bilim adamları ve iş insanlarının öğrenmeye devam edebilecekleri bir literatür bütünü yaratır. Araştırmalarının derinliği ve uygulanabilirliği, fikirlerinin zaman içindeki dayanıklılı̆ıyla birleştiğinde, günümüzün

\footnotetext{
${ }^{1}$ Nuray AKAR, Doktor Öğretim Üyesi, Akdeniz Üniversitesi, Uygulamalı Bilimler Fakültesi, Yönetim Bilişim Sistemleri Bölümü, nurayyapici@akdeniz.edu.tr, ORCID ID orcid.org / 0000-0003-2444-1233; Onur DiRLiK, Doktor Öğretim Üyesi, Eskişehir Osmangazi Üniversitesi, İktisadi ve İdari Bilimler Fakültesi, İşletme Bölümü, onur@ogu.edu.tr, ORCID ID orcid.org / 0000-0002-7045-0774
} 
pazar kargaşasına yanıt bulmak için birçok ipucunu hâlâ barındırdığını göstermektedir. Bir yönetim öncüsü olarak Barnard, dinlemeye istekli olanlar için bizlere yeni dünya düzeni için dahi iç görüler sunmaktadır (Malcolm ve Hartley, 2010). Örneğin günümüzde örgüt içindeki yönetimin kasıtlı, bilinçli, hiyerarşik ve otoriteye dayalı olduğu neredeyse mantıksal olarak kabul edilir. Chester I. Barnard genellikle bu görüşün ilk savunucularından biri olarak anılır. Hatta Barnard'ın daha sonra yayınlanan çalışmasında ve özel yazışmalarında bu bakış açısını daha da geliştirdiği ortaya çıkmaktadır. Aynı zamanda, firma içindeki koordinasyonun kendiliğinden doğasını nasıl keşfettiğini, firma içindeki koordinasyonun "görünmez el" açıklamalarını nasıl tartıştığını ve firma içindeki koordinasyonu piyasa koordinasyonu ile nasıl karşılaştırdığını anlatan çalışmaları günümüz örgütleri için bile oldukça açıklayıcı niteliktedir (Walsh ve Brady, 2019).

Bu makalede, Chester Irving Barnard'ın yönetim teorisine katkıları ve söylediklerinin günümüzdeki yansımaları irdelenecektir. Böylece, yönetim literatüründeki temel eserlerin, günümüz örgütlerine ışık tutan yönleri üzerine yeni bir tartışma alanı yaratılması amaçlanmaktadır.

\section{Barnard'ın Yönetim Tarihindeki Yeri}

Klasik yönetim düşünürleri ile aynı döneme denk gelen Barnard'ın yönetim yazınındaki katkısının, bakış açısındaki farklıı̆̆ın anlaşılması ve ileri sürdüklerinin irdelenebilmesi için öncelikle klasik yönetim düşüncesinin sunduğu temel argümanlardan bahsetmek doğru olacaktır.

Klasik yönetim düşüncesi örgütün verimliliğini, üretim sürecinin rasyonelliğine dayandırmaktadır. Temel sorunsalı oluşturan verimlilik, kaynakların ekonomik bir biçimde kullanılmasıyla ilgili olup mekanik bir süreçtir. Bu kapsamda ele alınan insan ussal bir varlıktır. Bu nedenle insanların yönetiminde kişi ve grupların akılcı davranışları önem taşır. Kişiler üstlerinin rehberliği olmadan pozisyonlarının gerektirdiği ilişkileri yürütemezler. Varsayım olarak görevlerin sınırları belirlenmedikçe ve bu sınırlar içinde kalmaya zorlanmadıkça kişiler yetkileri dışına çıkarlar. Bu nedenle faaliyetlerin, önceden tahmini ve faaliyetler arasındaki ilişkilerin düzenlenmesi, görevlerin önceden belirlenmesi ile mümkündür. Yönetim esas itibariyle bireylerin biçimsel faaliyetleri ile ilgilenir. Bu düşünceye göre, koordinasyon gönüllü olarak gerçekleşmez. Üst kademeler tarafından planlanmalı ve kontrol edilmelidir. Yetki, örgütün en üst kademesinde toplanmalıdır. Ayrıca bu düşünceye göre uzmanlaşma verimliliği artırmakta, kontrolü kolaylaştırmaktadır. Yönetim fonksiyonları belli bir şekilde yerine getirilir. Kişisel ve çevresel faktörlerden etkilenmez. Klasik yönetim düşüncesine göre insanlar genel olarak tembeldir, zorlanmadıkça çalışmazlar. Bu nedenle cezalandırma ve mükâfatlandırma yolu ile çalışmaya zorlanmalıdırlar. Tabiatları gereği pasiftirler. Hata yapmaya yatkındırlar, hata yapmaları önlenmelidir. Karar verme bakımından yetersizdir. Bu nedenle karar verme hakkı insanlara bırakılmamalıdır. Bu kadar keskin hatları olan klasik yönetim düşüncesi, daha sonraları alacağı önemli eleştirilere rağmen; modern yönetim biliminin yapı taşı olarak kabul edilmekte, ortaya attığı ve tanımladığı kavramlar itibariyle büyük ölçüde bugün bile kullanımaktadır. Bu akım, 20. yüzyıın başlarına damgasını vurmuş ve 1940’lı dönemlere kadar hakim görüş konumunda yer almıştır.

1920-1940 yılları arasında Oliver Sheldon, Mary Parker Follett ve Chester Irving Barnard; fikir ve görüşleri, uygulama alanında edindikleri tecrübelerle, klasik yönetim düşüncesine önemli katkılarda bulunmuşlardır. Bu önemli düşünürler, yaşadıkları dönem itibariyle klasik dönem düşüncesinin hakim olduğu döneme rastlamakla birlikte; fikir ve görüşleri, klasik yönetim düşüncesinin ötesine uzanmıştır. Çalışmalarında klasik dönem düşünürlerinden farklı olarak yönetim fonksiyonları çerçevesi dışına çıkıp, araştırma kapsamlarını genişletmişler ve aynı zamanda düşüncelerini felsefi bir yaklaşım içinde sunmuşlardır. Ayrıca klasik yönetim düşüncesini oluşturan kavramlara getirdikleri yeni açıklamalarla bu kavramlara yeni boyutlar kazandırmışlardır. Sosyolojik ve psikolojik yaklaşımla dönemleri için orijinal ve farklı fikirler ileri sürebilmişlerdir. Bu nedenle adı geçen düşünürler alan yazında "yönetim felsefecileri" olarak adlandırılmakta, fikir ve görüşleri yönetim felsefesi adı altında ayrı bir grup olarak ele alınmaktadır. Aynı zamanda bu düşünürler klasik ve neo-klasik dönem arasında bir köprü vazifesi görmüştür. Barnard’ın fikir ve görüşleri, sistem teorisine kadar uzanmıştır.

Chester Irving Barnard (1886-1961), iletişimi yönetimin temel fonksiyonu olarak görmekte, örgütte koordinasyonun önemini vurgulamakta ve işbirliği sürecinde gönüllülük esasının altını çizerek ortak amaçlara işaret etmektedir. Örgütün iç ve dış çevresini bütüncül bir bakış açısı ile ele alan ve sistem yaklaşımını öne süren Barnard, bireylerin 
örgütler için stratejik faktörler olduğunu belirterek formel ve informel örgüt yapısının birlikte ele alınması gerekliliğini savunmaktadır. Örgütsel gerçeklere elitist bir bakış açısı ile yaklaşan ve gerçek bir entelektüel olan Barnard'ın yabancı dil merakı, multidisipliner ve seçmeci okumaları, iyi bir katılımcı ve bilimsel gözlemci oluşu, sahip olduğu yöneticilik kariyeri, Gestalt psikolojisi temelli felsefi yaklaşımı, hem kamu kurumları için hem de özel sektör için çift yönlü olarak görüş bildirmesi onun düşüncelerine güçlü bir temel oluşturmaktadır (Barnard, 1938; Dunphy ve Hoopes, 2002: 1024; Gabor, 2000: 67; Resource Business Thinking, 2003: 73).

\section{Barnard'ın Döneminin Karakteristikleri}

İki dünya savaşı arasındaki dönem olan 1920 ve 1930 yılları arasındaki on yıl yönetim tarihi açısından önemlidir. Çünkü bu dönemde, ulus modernize olmuş, yönetsel durum yaratılmış, yeni yönetim sınıfı türemiş, sosyal bilimler keşfedilmiş ve Amerika'nın güç yapısı değişime uğramışır. Dolayısıyla yönetim 1920 ve 1930 'lu yıllar arasında evrimsel bir süreç yaşamıştır. Toplum mühen disliği ve davranış bilimleri, yönetsel serbesiyetçiliğin merkezi hâline gelmiştir. Bu yüzylın başında yönetim alanında rasyonalite, etkinlik, yetkinlik, ahlaki bütünlükile ilgili değerler gibi toplum için felaket getiren aşamalı radikal reform hareketleri ortaya çıkmışıı. Amerika ve müttefikleri birinci dünya savaşına katıldı̆̆ında bu değerler ideolojik olarak yönetimde birleşmeye başlamışıı. Tarihçi Dawley bu durumu, yönetsel serbesiyetçilik olarak adlandırımışıır. Yeni elit tabaka yaratılırsa, halk yönetim kurallarının meşruluğunu kabul edecektir. Rasyonalite ve teknoloji, sınıfsal çatışmalar ve işgücü hareketleri, kamunun refahı ile sosyal ve ekonomik politika alanlarında liderlik başarısız olmuştur. Tüm bu alanlarda Amerikan toplumunda kentleşme, endüstrileşme ve kitleselleşme gibi yapısal değişimler söz konusu olmuştur. Denge için sınıflar arasında işbirliği gerekmektedir. Toplum mühendisliği söz konusu işbirliğini yaratabileceğini vaat etmiştir. Amerika ve Avrupa arasında toplum mühendisliği konusunda farklılk yaratan belirgin bir özellik vardır. Avrupa'da toplum mühendisliği kamuya yönelik iken, Amerika'da özel sektöre yönelik olmuştur. Ekonomik felakette çalışanların davranışlarını kontrol edebilmek için sosyal bilimlere başvurulmuştur. Barnard, yönetsel serbesiyetçiliğin en etkili savunucusu hâline gelmiştir. Yönetsel serbesiyetçilig̈in temel ideolojisi; elitist, manipülatif, baskıcı ve genellikle sosyal ve ekonomik düzeni ayakta tutmayı destekleyen tarzdadır. Hoover, Barnard ve Lippmann, ulusal gücün profesyonel yöneticilerin ellerinde olduğunu tartışarak; söz konusu reformu, New York'un en büyük kanun koyucu kurumlarından olan endüstriyel şirketlerde, ortaklıklarda ve finansal bankacilık kurumlarında yerleştirmek istemişlerdir. Örgütlerin geniş ve karmaşık bir boyuta gelmeleri de yöneticilerin becerilerine bağlıdır. Yönetsel serbesiyetçiliğin ardındaki etkinlik düşüncesi, bilimsel yönetimin öncüllerinden türemiştir. Kaynakların rasyonel kullanılması sonucunda maliyetler düşsmekte, verimlilik artmakta, yaşam standartları gelişmekte ve işgücü barışı sağlanmaktadır. Toplum mühendisliğinin temellerinin 1920'lerin örgütsel psikoloji hareketine dayandığı düşünüldüğünde, Hawthorne Araştırmaları ile Rockefeller Vakfı, Harvard ve Amerikan Telefon ve Telgraf Şirketi (AT\&T) gibi kurumların sosyal bilimlere mali destek sağlamaları öne çıkmaktadır. Örneğin; ikinci dünya savaşının başlangııında, sosyal istikrar ve ekonomik refahı etkileyebilecek profesyonel modellerle hizmet verebilme peşinde koşan AT\&T Şirketi, laboratuvarlarını bilimsel araştırmaların yapıldığı güçlü bir bilim evi hâline getirmeye ve bilimsel üretim metotlarına öncülük etmeye başlamıştır. 1920'lerin başında da Hawthorne Araştırmaları'ndaki deneyimleri ile ün kazanan Ulusal Bilimler Akademisi ile işbirliğine gitmiştir. Barnard'ın kitabını yazdığı 1938'lerde Amerikan girişimleri 1930'ların büyük buhranı ile başa çıkmaya çalışmaktaydılar. Bu dönemlerde çok sayıda vatandaş büyük işletmelerin toplumdaki rolünü sorgulamaktaydı. Birçok Amerikall, AT\&T Şirketi'nin büyük buhran süresince oynadığı rolü incelemekteydi. AT\&T Şirketi'nin yatırımcıları, daha fazla kâr için şirketin çalışanlarını feda etmekteydi. Şirket küçülme stratejisi izliyordu. Yöneticiler bu durumu, üretim hızını arttırabilmek için yeni teknolojilere uyum sağlayabilme amacıyla açıklamışlardı. Bu noktada, Abrahamson'un (1997) performans açığı ve sarkaç-salınım tezi akla gelmektedir. Özetle, birinci dünya savaşının Amerika Birleşik Devletleri'ne etkisi; AT\&T Şirketi'nin devletle, maliyeyle ve kamu kurumlarılya ilişkisi; Barnard'ın Harvard'ı arkasına alması; sosyal kapitalizmin güçlendirilmeye çalışıması; Barnard'ın yöneticilere liderlik yaparak düşüncelerini halka ulaştırmaya çalışması gibi karmaşık bir yapı sergileyen dönemin önemli karakteristikleri arasında sayılabilmektedir. Barnard, böyle bir ortamda, endüstriyel toplumlarda hakim olan elit tabakanın yönetsel meşruiyetini sağlamak, toplumların örgütlenmesinde kilit faktör olarak yöneticilerin rolü ile ilgili bilgi vermek, yeni endüstriyel çağda meşru yönetimin doğrularını ve yükümlülüklerini modern uluslara taşımak amacıyla "The Functions of the Executive" adlı kitabı yazmıştır. Hem bir yönetim kuramcısı hem de başarılı bir uygulamacı olan Barnard, 1909 ylında Amerikan Telefon ve Telgraf Şirketi'nde çalışmaya başlamıştır. Büyük buhran boyunca New Jersey Devlet Yardım 
Sistemi'ni yönetmiştir. Ayrıca kamuda, sosyal hizmetler kurumlarında ve vakıflarda da görev yapmıştır (Gabor, 2000: 67; Gehani, 2002: 983; Pye, 1994: 1129; Scott, 1994).

\section{Chester Irving Barnard'ın Yönetim Teorisine Katkıları}

Chester Irving Barnard’ın yönetim yazınına kazandırdıklarını incelemeyi amaçlayan bu çalışma, temel olarak düşünürün "The Functions of the Executive" ve "Organization and Management: Selected Papers" adlı kitaplarının, çeşitli makalelerinin ve Barnard ile ilgili görüş bildiren farklı eserlerin taranmasına dayanmaktadır.

\section{1. İşbirliği Sistemi Olarak Örgütler}

Birey ve örgüt kavramsallaştırmaları ile büyük bir katkı sağlayan Chester I. Barnard’a göre, birey ve örgüt iki uç noktayı temsil etmektedir. Çünkü, irrasyonel olan bireyin amaçları şahsi, rasyonel olan örgütün amaçları ise gayrişahsidir. Bireylerin fiziksel, biyolojik, kişisel ve sosyal olarak birtakım kısıtlılıkları söz konusudur. Dolayısıyla bireyleri sınırlayan olguların üstesinden gelinebilmesi için işbirliği sistemi kurulmakta ve bu noktada grup içindeki birey önem kazanmaktadır. Bu bağlamda, bireysel eğilimler psikolojik olaylara, işbirliği ise sosyal olaylara işaret etmektedir. Devamlılığı etkinlik ve etkililik gibi iki faktöre bağlı olan işbirliği sistemi "iki veya daha fazla kişinin işbirliği sebebi ile özel sistematik bir ilişki içine girmesi sonucunda oluşur ve fiziksel, biyolojik, kişisel ve sosyal bileşenlerin bir karışımı"dır. Belirli bir amacı gerçekleştirmek üzere iki veya daha fazla kişinin çabalarını bilinçli olarak birleştirmeleri yoluyla ortaya çıkan işbirliği sistemine "girişim", "iş" ya da "işletme" denilebilir, ama "örgüt" daha kapsamlı bir kavramdır. Bu bağlamda, iş örgütlerinin ana amacı hizmet sağlamaktır; kâr, güç, politik ideoloji ya da bireysel kazanç değildir. Beşeri faaliyetlerin bir fonksiyonu olan işbirliği sistemi şeklinde tanımlanabilen örgüt, fayda yaratılmasını, dönüştürülmesini ve mübadeleyi içermektedir. Formel örgüt "aralarında sistematik ilişkiler olan fiziksel, biyolojik, psikolojik ve sosyal öğelerden oluşan, iki veya daha fazla sayıda insanın faaliyetlerini bilinçli olarak koordine ettiği bir işbirliği sistemi"dir. "iki veya daha fazla bireyin bir gücü" olarak "beşeri çabanın koordine edilmiş gayrişahsi bir sistemi" gibi nitelendirilebilen formel örgütün yanı sıra "insan gruplarının ilişkilendirilmelerinden doğan ve kişisel temas ile etkileşimlerin bir bütünü olan tanımlanmamış yapılar" da söz konusudur ki bunlara informel örgüt denir. Söz konusu işbirliği sisteminde yöneticiler "örgütteki değerlerin hem yürütücüsü hem de oluşturucusu" olarak görev almaktadırlar. Bu bağlamda, Barnard'ın yönetici tanımının, tek tarafıı ve otokratik bir tarzdan ziyade işbirliği ve demokrasi temeline dayandığı söylenebilir. Sosyal bir sistem olan örgütün unsurlarını; iletişim, hizmet isteği ve ortak amaç olarak sıralayan Barnard, yönetimin daha çok ahlaki ve kültürel yönünü vurgulayarak, söz konusu unsurların birbirine bağımlı ve birbiriyle etkileşimli olduğunu belirtmiştir. Barnard'ın oluşturduğu işbirliğine dayanan düzlem, onun otoriter yönetim felsefesinden uzaklaşmasına neden olmuştur. Söz konusu sistemin devamlılığı, her bir bireyin sisteme katkısı ile sistemden duyduğu tatmin arasındaki dengeye bağlıdır. Bu noktada "sistemin kişisel olmayan ve sosyal nitelik sergileyen ortak amaçlarının başarılması ve gerekliliklerinin karşılanması" etkililik, "kişisel nitelik sergileyen bireysel güdülerin tatmini" ise etkinlik olarak tanımlanmaktadır. Yani örgütün ömrü, örgüt amaçlarının gerçekleştirilmesine ve üye ihtiyaçlarının karşılanmasına bağlıdır. Dolayısıyla üyenin örgüte katkısı ile örgütün üye ihtiyaçlarını karşılaması arasındaki denge, örgütün varlığı ve devamlılığı açısından önemlidir. Çünkü işbirliği sadece liderin sorumluluğunda değildir, örgütün tamamını ilgilendirmektedir (Barnard, 1938; Gehani, 2002: 987; Wolf, 1994: 1047).

Birey ve örgüt ayırımı, yönetimin fonksiyonları ve söz konusu fonksiyonların yönetilmesi süreci ile ilgili açılımları ile işbirliği sistemi, formel ve informel örgüt, etkinlik ve etkililik, yönetici, liderlik, ahlak, otorite, otoritenin kabul kuramı ve kayıtsızlık bölgesi tanımlamaları Barnard’ın yönetim yazınına sağladığı katkılar arasında sayılabilir. Harvard tarafından 1938 yılında basılan "The Functions of the Executive" adlı kitabı, kutsal kitap muamelesi görmekte; 20. yüzyılın en etkili yönetim kitabı ve örgüt sosyolojisi ile örgüt teorisinin öğretilmesinde temel bir kaynak olarak nitelendirilmektedir. Alan yazına göre, Barnard'ın söz konusu kitabı, kamu yönetiminde en fazla atıf alan ikinci kitaptır. Kitabın ilk iki bölümü, işbirliğinin yapısı ve anatomisi üzerine; sonraki iki bölümü ise, işbirliğinin fizyolojisi ve ekonomisi üzerinedir. Kitapta örgütün yapısal kavramları arasında birey, işbirliği sistemi, formel ve informel örgüt; dinamik kavramları arasında ise iletişim, otorite, karar süreçleri ve dinamik denge gibi olgulara yer verilmektedir. Yönetimin 
fonksiyonlarını inceleyerek yöneticilere önerilerde bulunan Barnard'ın asıl amacı, fonksiyonalistler gibi "ne işe yarar" diye sorgulamak değil; yönetim işini kolaylaştırıp daha insancıl bir hâle getirmektir. Bu noktada, yönetimin "bir sanat mı, yoksa bir bilim mi" olduğu tartışılmaktadır. Barnard'a göre yönetim, bilimsel temel ve uygulama olarak iki ayaklıdır. Bilimsel temel, yönetimin bilim ayağını oluştururken; uygulama aşaması, yetenek gerektirmesi bakımından yönetimin sanat ayağını oluşturmaktadır. Ayrıca pozitivizmin bir eleştirisi olarak, sosyal meselelerin içinde barındırdığı ekonomik, politik, estetik, dini vb. motifler dolayısıyla durumun karmaşık olduğu ve sosyal bilimlerde kalıplaşmış bilginin olmayacağı gözden kaçırılmamalıdır. İnsan davranışlarının öngörülememesi nedeniyle bir sosyal bilimcinin, bir fizikçi ya da kimyacı gibi tanımlanmış çözümler ortaya koymasının beklenemeyeceği, kontrollü deneylerin sosyal bilimler için yetersiz olduğu ve bu alanda felsefik temelin gerekliliği ifade edilebilir (Barnard, 1938; Mahoney, 2002: 159; Parayitam, White ve Hough, 2002: 1004; Pye, 1994: 1127; Scott, 1982: 197; Üsdiken, 2002: 135).

Vizyonu, rasyonalite ve fonksiyonel ahlak gibi ideolojik yönetim kuralları ile dolu olan Barnard, örgütlere beşeri faaliyetlerin ve işbirliğinin bir sistemi olarak bakmıştır. Formel örgütün işlevlerini başarıyla yapabilmesi için informel örgütün zorunlu olduğunu belirten Barnard; örgütü, bireyler arasında bilinçli, maksatlı ve amaca yönelik işbirliğinin bir türü olarak görmüştür. Yani örgüt, bilinçli bir şekilde oluşturulmuş değerlere ve koordine edilmiş eylemlere dayalı olan ve iki veya daha fazla kişinin güçlerinin ve faaliyetlerinin eşgüdümlendiği bir işbirliği sistemidir. Bir etkileşim sistemi olan örgütlerin devamlılığı için gerekli olan iki kriter vardır. Bunlar; etkinlik ve etkililiktir. Genel anlamda etkinlik, önceden belirlenmiş hedeflere ulaşabilmektir. Barnard'ın etkinlik tanımı, geleneksel tanımdan farklıdır. Barnard, işbirliği yapmak isteyen yeterli sayıda bireyin sağlanması yolu ile test edilen etkinliği, örgütün bireyleri ne derece motive ettiği ve bireylere ne derece tatmin sağladığı ile ilişkilendirmiştir. Eğer örgüt, bireyleri tatmin edebilir ve önceden belirlenmiş hedeflere ulaşılabilirse, bireyler arasındaki işbirliği bozulmaz. Yöneticiler için işbirliği çekicidir. Çünkü, işbirliği ile sinerji yaratılarak, bireylerin kendi başlarına sarf ettikleri çabadan daha büyük bir sonuç başarılmaktadır. İ̧̧ yükünün paylaşılması, örgütün rekabetçi performansına katkıda bulunmak için çalışanları harekete geçirir; psikolojik tatmin sağlar ve maddi teşvikler gerektirir. Dolayısıyla örgüt ve birey için ideal bir sonuç olan, örgütün ve bireylerin amaçlarının başarılması arasındaki uyumu ifade eden ve "işbirlikçi bir sistemin kapasitesi" olarak tanımlanabilen denge durumunda, örgütün performansı arttıııırken, çalışanların tatmini de sağlanmış olacaktır (Barnard, 1938; Gehani, 2002: 986).

\subsection{Yönetimin Üç Fonksiyonu}

Bilimsel yönetim dönemi sürerken Barnard, informel yapı tarafından geliştirilen davranış ve düşüncelerin tanımlanmış şekli olan formel örgütlerin analizini ortaya koymuş ve yönetimin üç fonksiyonu olduğunu varsaymışır. Barnard'a göre yönetimin ilk fonksiyonu, iletişim sisteminin kurulması ve sürdürülmesi; ikinci fonksiyonu, önemli hizmetlerin kişisellikten kurtarılması ve üçüncü fonksiyonu, örgütsel amaç ve hedeflerin belirlenmesidir. Bu bağlamda, genel yönetim sürecinin estetik ve ahlaki olduğunu; uyum, kapasite ve sorumluluk içerdiğini belirtmiştir. Ayrıca sadece yönetimin fonksiyonlarını ortaya koymakla kalmayıp bu fonksiyonların yönetilmesi sürecini de açıklamıştır. Bu görüşleri, yönetim disiplininde yankı uyandırmış ve Barnard'ın "kişsisel gücün eski dünyasını, örgütsel kontrolün modern dünyasına birleştirerek yönetimin geçmişi ile geleceği arasında entelektüel bir köprü inşa ettiği ve klasikler ile neoklasikleri birbirine bağladığı" ifade edilmiştir. Scott da Barnard'ın "klasik örgüt kuramını, Fayol'un fonksiyonel yaklaşımını ve teknik rasyonaliteyi günümüzün işbirliği içinde çalışan bireylerinin ihtiyaçlarını vurgulayan karmaşık örgütleri ile ilişkilendirdiğini" belirtmiştir (Barnard, 1938; Parayitam vd., 2002: 1003).

Barnard, yönetimin birinci foksiyonunun örgütsel iletişim sisteminin kurulması, geliştirilmesi ve korunması olduğunu belirtmiştir. İ̧̧birliği sisteminin temeli, koordinasyon çabası gerektirmesidir. Bu da örgütlerde iletişim sistemi olarak kendini göstermektedir. Iletişim sistemi, bağlantı noktalarını ve merkezlerini ifade etmektedir. Bu merkezler, üst yönetim tarafından idare edilmektedir. Yönetimin görevi bir iletişim kanalı gibi hizmet vermektir. Bu, organizasyon şemasını ve yönetim personelini kapsamaktadır. Bu süreçte bireylerin seçimi, teşvik edilmesi, kontrol teknikleri, personelin yükseltilmesi, rütbe indirimi, 
işten çıkarma, informel yapının korunması, kişilerin temel özelliklerinin uyumlu olması vb. hep birlikte önem taşımaktadır. İkinci fonksiyon ise, önemli hizmetlerin gayri şahsileştirilmesi kapsamında işbirliği için gönüllülük yaratılmasıdır. Bu noktada, bireylerin işbirliği sisteminin içerisine çekilebilmesi için teşvikler devreye girmektedir. Her birey farklı teşviklerle motive olmaktadır. Önemli olan, bireylerin işbirliği yapmaya ikna edilmesi ve işbirliğinin sürdürülmesidir. Üçüncü yönetim fonksiyonu "sistem", "koordinasyon" ve "işbirliği" kavramlarının bir gereği olarak ortak bir amacın varlığı ile ilgilidir. Yönetimin görevi, işbirlikçi çabanın korunması ve sürdürülmesi için uzmanlık gerektiren görevleri yerine getirmektir. Bunun için ortak amaçlar belirlenmeli ve hangi işlerin yapılacağı kararlaştırılmalıdır. Daha sonra söz konusu işleri örgütte düzenli olarak kimin yapacağı planlanmalıdır. Bu bağlamda, yetki devri kritik bir duruş sergilemektedir. Her çalışan; örgütün, kendi biriminin ve kendi görevinin amaçlarının farkında olmalıdır. Bu noktada, sosyal tatmin için somut amaçların varlığı ve örgütsel amaçlar ile bireysel amaçların birbirini karşılaması önem taşımaktadır. Çünkü, somut amaçların olmadığı durumlarda Fransız Sosyolog Durkheim'in "anomie" olarak tanımladığı uyumsuzluklar ortaya çıkmaktadır. Amaçlar konusunda da ikna ve teşvik yöntemleri işlerliğini sürdürmektedir. Kişisel ödüllerin, örgütsel amaçların başarılmasından doğacağı dikkatten kaçırılmamalıdır. Bu noktada, motivasyon için Maslow'un kendini tamamlama ihtiyacına karşılık olarak zor amaç ve görevler benimsenebilir (Barnard, 1938; Parayitam vd., 2002: 1004).

\subsection{Formel ve İnformel Örgüt Tanımlaması}

Formel örgütleri "kişisel olmayan" ve "sosyal durumlar" olarak nitelendiren Barnard'a göre, söz konusu örgütlerdeki çalışanlar "gerekçeli ve hesaplanmış eylemlere ve politikalara" uyum göstermektedirler. Formel örgütler, uzmanlaşma ve koordinasyonun karşıt güçlerini uyumlaştırmak için tasarlanan bilinçli yapılardır. Fiziksel, biyolojik, kişisel ve sosyal bileşenlerin bir karmaşası olan örgüt, büyük bir sistemin alt sistemidir. Diğer örgütler de söz konusu işbirliği sisteminin sosyal çevresinin birer parçasıdır. Bu durum, açık sistem yaklaşımı ile daha büyük sistemlerin, alt birimleriyle olan etkileşimi şeklinde açıklanabilir. Üst sistemler, alt sistemlerden daha kapsamlıdır. Alt sistemler, üst sistemlere göre sınırlandırılmış parçalardır. Barnard sadece formel örgütü tanımlamamıştır. Aynı zamanda informel yapının örgüt için önemini de açıklamıştır. Barnard, informel yapıyı kendiliğinden oluşan kişisel ilişkiler yığını, beşeri gruplar arasındaki etkileşimler ve bireylerin bilinçaltı veya zihinsel olmayan hareketleri ile alışkanlıklarının meydana getirdiğini belirterek, bireylerin temel gereksinimlerinin beşeri nitelikteki ilişki kurma ihtiyacı olduğunu vurgulamıştır. Acı veren büyük buhranın bir meyvesi olarak oluşan informel örgüt yapısının, çalışanların kişisel bütünlüğünün ve haysiyetinin korunmasına yardım ettiğini ifade etmiştir. Formel örgüt yapısının altında oluşan durumu yansıtan informel örgüt yapısı; çalışanları kurallar, düzenlemeler ve formel örgüt yapısının saldırılarıyla yüzleşmekten korumaktadır. İnformel örgüt yapısı sonucunda, özellikle sosyoloji, sosyal psikoloji ve antropoloji açısından önem teşkil eden, belli başlı davranışlar, yaklaşımlar, idealler, alıskanlıklar, huylar, töreler, mitler, sosyal normlar, kurumlar vb. meydana gelmektedir. Ancak sosyal olmayan maddi gereksinimler sonucunda çıkar çatışmaları, husumet, düşmanlık ve düzensizlik yaratılabilmektedir. Olumsuz karakterlerin etkileşimi de uyuşmazlık yaratmaktadır. Bireyin tam serbestisi ise anarşiye yol açmaktadır. Ortak amaçların kabulü, iletişim, işbirliği isteği gibi meseleler öncelikli temas ve ön etkileşim gerektirdiğinden informel yapının, kökeni spontane olan formel yapıdan önce geldiğini belirten Barnard, informel örgüt yapısının formel örgüt yapısı kadar gerekli ve kaçınılamaz olduğu görüşündedir. Teknolojik gelişmeler sonucunda sanallık artmakta ve duyarsızlaşma eğilimi sergilenmektedir. Dolayısıyla örgütlerde teknik boyutun yanı sıra beşeri boyuta da önem verilerek denge sağlanmalıdır. Bu bağlamda üyelik hissi ile aidiyet yaratılması önem taşımaktadır. Ancak bu noktada, yöneticiler genellikle informel örgütlerin varlığını inkâr etmekte ya da görmezden gelmektedirler (Barnard, 1938; Gehani, 2002: 987).

Formel işbirliği sisteminin vazgeçilmez ve en önemli parçası olan informel yapının fonksiyonları; iletişim, gönüllü katılım ile kişisel bütünlük hissinin, özsaygının ve özgür seçim hakkının korunmasıdır. İnformel yapı için tanımlanmış olan üçüncü fonksiyon, formel yapıya zarar veren bir özellikmiş gibi düşünülse de formel yapının içinde bireyin kişiliğinin korunması ile ilgilidir. Bu bağlamda, informel yapının temel fonksiyonları, formel yapının devamlıı̆ı̆ı için iletişimin genişletilmesi, istenmeyen etkilerin en aza 
indirgenmesi ve istenen etkilerin arttırılması olarak özetlenebilir. İnformel örgütlerin yönetim fonksiyonları, fiziksel varlı̆ı̆ olmayan iletişime, olaylara, düşüncelere, önerilere ve şüphelere dayanmaktadır. Bu unsurlar, formel kanallardan geçemezler. İnformel örgütlerin kendi öz disiplinleri ve grup normları vardır (Barnard, 1938).

İlişkilerin fizyolojisi ile insan anatomisi arasında kurduğu bağlantıda iskelet metaforunu kullanan Barnard, formel örgütü beden, informel örgütü ruh ve iletişim kanallarını ise damarlar olarak nitelendirilmiştir. Formel ve informel yapının, aynı olgunun birbirine bağlı görünüşleri olduğunu ifade eden Barnard, toplumun formel örgütler tarafından yapılandıııldı̆ıını, formel örgütlerin de informel örgütler tarafından düzenlendiğini ve hayat bulduğunu belirtmiştir. Örgütün kendisinin bir parçası olan yönetici tarafından yönetilmediğini, bir bütün olarak kendi kendine yönetildiğini vurgulayan Barnard, bu durumu da insan vücudundaki kapsamında beyni de bulunduran ve otonom olarak çalışan sinir sistemi ile ilişkilendirmiştir. Çünkü yönetimin fonksiyonları, işbirliği sisteminin çabalarını idare etmek için vardır ve büyük bir örgüt sorumluluk devri olmadan yönetilemez. Bu noktada lider de iletişimin merkezi ve orkestranın şefidir (Barnard, 1938; Pye, 1994: 1134; Smith, 1994: 1159).

\subsection{Iletişim Sistemine Dayalı Otorite ve Teşvik Yaklaşımı}

Örgütsel eylemlerin iletişimi içermesi gerektiğini düşünen Barnard, iletişim sistemi bağlamında yedi temel kuraldan söz etmiştir. Bunlardan bazıları iletişim kanallarının belirli olması, ulaşılabilir olması, formel olması, kısa ve doğrudan olması ile ilgili meselelerdir. Ayrıca gönderilen mesaj; açık, net, yapılabilir, bireysel ve örgütsel amaçlarla uyumlu olmalıdır. Astlar tarafından kabul görmeyen bir otoritenin hiçbir işe yaramayacağı inancında olan Barnard'ın iletişim anlayışında amirlerden ziyade astlar birer iletişim otoritesi hâline dönüşmüşlerdir. Dolayısıyla yönetici astlarına saygı çerçevesinde davranmalı ve otoriteyi becerikli bir şekilde sağlamalıdır. Bu noktada teşvik yaklaşımı devreye girmektedir. Maddi teşvikler ve ikna gibi iki olgudan bahseden Barnard, formel bir örgütün kuramsal boyutu ile beşeri boyutu arasındaki uyuşmazlıkların önüne geçilebilmesi için iknaya daha fazla önem vermektedir (Barnard, 1938; Parayitam vd., 2002: 1004; Scott, 1982: 198).

Ahlak "iyi-kötü", değerler "doğru-yanlış" ölçütleri ile ilgilidir. "Bireyde ortaya çıkan dış kuvvetler" olarak nitelendirilen ahlak kararları, örgüt için "neyin iyi-neyin kötü" olduğu ile bağlantılıdır. Barnard'ın ahlak tanımı, kişisel özelliklere yönelik bir tanımlamadır ve karaktere işaret etmektedir. Yönetimin sorumluluğunun bir unsurunun örgütün amaç ve değerlerini beslemek olduğunu ve bunların eyleme dönüştürülmesi gerektiğini belirten Barnard'a göre, değerler "kendi çıkarlarına bağlı olmaksızın veya kararın sonuçlarını önceden kestirmeksizin inançlarla veya sezgilerle belirlenmiş doğru ve yanlışlar" ve ulaşımak istenen ideal durumlardır. Yani olması gerekeni gösterirler. Normatif davranışlardan veya standartlardan oluşurlar. Bu noktada, değer kavramının, ahlak kodlarına atıfta bulunduğu söylenebilir. Sorumluluk ise, "bireylerin davranışlarında etkili olan ahlak temelli kişisel özellikler" olarak tanımlanabilir. Bu bağlamda, ahlak kavramının, sorumluluk ile değerler arasına düştüğü ifade edilebilir. Sorumluluk hissi gerekli, fakat büyük ölçüde gelişmiş değer sistemi ile desteklenmedikçe yetersizdir. Örgüte bir toplumsal sistem olarak yaklaşan ve örgütlerde temel kavram olarak değerler üzerinde duran Barnard, yönetimin temel görevinin örgütün değerlerini biçimlendirip yönetmek, örgütteki toplumsal güçleri dizginlemek ve örgütsel bütünleşmeyi sağlamak olduğunu vurgulamıştır. Yönetimin sosyo-psikolojik ve etik boyutuna dikkat çeken Barnard, ayrıca yöneticinin ahlaki ve kültürel yönden bir lider olması ve örgütsel kodlar yaratıp aşılaması gerektiğini savunmuştur. Bu, günümüz yazınındaki kültür, etik, örgütsel kimlik ve değişim kavramları ile davranış normlarına bir atıf olarak değerlendirilebilir. Yöneticiler için başarılı olma, ikna ve önsezi yeteneği gibi üç temel beceri öne süren Barnard, yöneticilere kişiler arası duygusal ilişki becerilerini, önsezilerini, ayırt etme güçlerini, belirsizlik ya da yetersiz bilgi durumlarıyla yüzleşme yeteneklerini geliştirmelerini önermiştir (Barnard, 1938; Gehani, 2002: 985; Smith, 1994).

Demokrasi, işbirliği sistemindeki davranışlarla ilgilidir ve liderler ile izleyicilerin davranışlarının karşılıklı uyumuna bağlıdır. Demokrasi süreci zarar gördüğünde, uyum bozulur, düzensizlikler, bölünmeler ve ayaklanmalar baş gösterir. Demokrasinin hasara uğraması, bireysel kısıtıııklardan kaynaklanmaktadır. 
Demokratik sistemin temeli, güven esasına dayanmaktadır. Söz konusu sistemde sadakat önemlidir. Dolayısıyla liderler, izleyicileri tarafından kabul edilebilir olanı ve neyin, nasıl yapılabilir olduğunu ayırt etme kapasitesine sahip olmalıdırlar (Barnard, 1956).

\subsection{Otoritenin Kabulü ve Kayıtsızıı Bölgesi}

Otoritenin pozisyondan veya bireyden kaynaklanmadığını, daha çok kişinin veya pozisyonun astlar tarafından kabul edilip edilmediğine yani fonksiyonel bağlantılara bağlı olduğunu ifade eden Barnard'ın "kabul kuramı" Follett'in "rıza gösterme" görüşüyle tutarlıdır. Bu noktada Follett'in "yetki durumdan doğar" anlayışı, Barnard'ın "otorite” kavramına temel sağlamış olabilir. Barnard, yöneticinin otoritesinin astlar tarafından demokratik bir yolla gönüllü olarak kabul görmesi gerektiği düşüncesindedir. Ayrıca otoritenin astlar tarafından kabul gördüğü takdirde meşruiyetine inanmaktadır. Barnard "kayıtsızlık bölgesi" kavramını, bireyin ilgilenmediği durumları ifade etmek için kullanmıştır. Simon (1965) ise, bu kavramı genişleterek, bireyin peşinen kabullendiği ve isteyerek uygulamaya hazır olduğu yönetici kararlarını içerecek şekilde "kabul alanı" olarak geliştirmiştir. Söz konusu kavramlar, astın soru sormaksızın boyun eğmeye razı olacağı otorite miktarı ile yönetimin isteğini yerine getireceği eylemler bölgesini anlatmaktadır. Bu noktada, otoritenin bireyler tarafından nasıl algılandığının ve otoritenin kapsamının irdelenmesi ile yönetici kararlarının sorgulanması ve olgunlaştırılması söz konusu olmaktadır. Barnard, yöneticilerin karar verme sürecinde bireysel ve örgütsel seviyede bir ikilem yaşadıklarını belirtmiştir. Bir örgütte yönetici, kolektif karar verme davranışının yanı sıra bireysel olarak da yer almaktadır. Yani ortak amaçların yanı sıra yönetici farklı bir fiziksel, biyolojik ve sosyal varlık görevi de icra etmektedir. Barnard için sorumluluk, otorite meselesinden daha önemli ve önceliklidir. Ayrıca bazı bilim insanları kayıtsızlık bölgesinin, Kohlberg'in ahlak geliştirme adımlarına benzediğini ileri sürmektedirler. Ahlaki gelişim aşamaları ilerlediğinde ve ahlak kodları iyi yerleştirildiğinde, kayıtsızlık bölgesi genişlemekte; dolayısıyla yöneticinin işi kolaylaşmaktadır (Barnard, 1938; Golembiewski ve Kuhnert, 1994: 1195; Rabin, 1994; Smith, 1994).

\subsection{Yetki ve Sorumluluk Tanımlaması}

Bir yönetim felsefecisi olan ve örgüt ile yönetime sosyolojik bir yaklaşım yapan Barnard'ın yetki görüşü, yetkinin kullanılmasından etkilenen kimseyi de dikkate alan, çift yönlü bir iletişime dayanmaktadır. Verilen bir emrin yetkiden destek görüp görmediği, emir alan kimsenin kabul edip etmemesiyle anlaşılır. Sorumluluk ise, bir yandan yetkiyi kullanma zorunluluğu diğer yandan da bundan kaçınma veya yanlış kullanma durumlarında suçlama görevi yapar. Sorumluluk aynı zamanda örgüte sadakatin de bir ifadesidir. Genel bakımdan sorumluluk, yöneticiyi değerlere aykırı zayıflık ve isteklerine karşı koruyan bir kavramdır. Özel bakımdan ise, sadece böyle bir ahlak ölçüsüne itaat etmeyi değil, başka ahlak kodları yaratmayı da gerektirir. Dolayısıyla sorumluluk ile ahlak aynı anlama gelmemektedir. Yani yönetimin görevi sadece ölçüm, kontrol ve nezaretçilik değildir. Yönetim değerlerle ilgilidir. Dolayısıyla iş yaşamında ahlaki ölçütler önemli bir yer tutmaktadır. Bu noktada yönetim sorumluluğunun ayırt edici özelliği, yöneticinin sadece var olan ahlaki kurallara uymak zorunda olmaması, aynı zamanda diğer çalışanlar için ahlaki değerler yaratmak ve bunlar arasında iletişimi sağlamak zorunda olmasıdır. Yöneticiler yetkiden çok etki yollarını kullanmalıdırlar. Bu bağlamda, emir alan kimseye kabul hakkı tanıyan yetki görüşü, çevresindekilerle etkileşim yapısı kurmak zorunda olan yönetici için daha yararlıdır (Barnard, 1938; Resource Business Thinking, 2003: 73; Scott, 1982: 197; Smith, 1994).

\subsection{Yöneticilik ve Liderlik Ayrımı}

Klasik yönetim anlayışının aksine, yöneticilik ile liderliğin birbirinden farklı olduğunu savunan Barnard'a göre, liderin fonksiyonu, izleyiciler için anlam yaratmaktır. Lider, her şeyden önce bir öğretmen olmalı ve izleyicilerine tam bir eğitmenlik desteği vermelidir. Kabullenilen ve izlenen kişi olan lider; değerleri öğreterek, yeni amaçlar koyarak, yeni standartlar oluşturarak, sınırlılıkları göstererek ve yöntemleri belirleyerek izleyicilerine kılavuzluk etmelidir. Ayrıca işbirliği sisteminde liderin koordinasyon yaratma gücü önem kazanmaktadır. Dolayısıyla liderlik "insanlara rehberlik eden ya da onların gayretlerini organize eden bireylerin davranışlarının kalitesi" olarak tanımlanabilir. Bu bağlamda liderlik süreci; lider, izleyiciler grubu ve koşulların bir fonksiyonudur. Liderlerin en belirgin görevi; ne yapılması gerektiğini, 
ne yapılmaması gerektiğini, nereye gidileceğini, ne zaman durulacağını, ortak niyet ve amaçların gösterilmesini, üstlenilmesini ve kavratılmasını bilmek, söylemek ve sağlamaktır. Dolayısıyla liderlerin öncelikli çabası; örgütün tüm sistem ve faaliyetlerinin korunması, sürdürülmesi ve eşgüdümlenmesidir. Farkındalık, cesaret gibi genel yetenekler doğuştan gelmektedir. Dolayısıyla liderler; kararlı, ikna edici, sorumluluk sahibi, entelektüel kapasiteli, dürüst karakterli, cesaretli ve inisiyatif sahibi olmalıdırlar. Özel yetenekler ise, işbölümü ve uzmanlaşma sonucunda eğitim ve geliştirme ile kazanılabilmektedir. Otorite ağının en üst pozisyonundaki kişi daha fazla genel yeteneğe sahip olmalıdır. Bu bağlamda, Barnard'ın katı bir özellikler yaklaşımı duruşu sergilemek yerine, özellikler yaklaşımının daha baskın bir şekilde hissedildiği davranışsal ve durumsal yaklaşımı da içeren bir duruş sergilediği söylenebilir (Barnard, 1938; Barnard, 1956).

\subsection{Yönetsel Karar Verme}

Fırsatçılığın temelini çevresel koşullarla bağdaştıran Barnard, büyük buhran ile başa çıkabilmek için yöneticilerin eğitilmesi gerektiğini ileri sürmüştür. Burada teknik eğitimden ziyade, sosyal olayları algılamaya yönelik eğitimler kastedilmektedir. Ayrıca uzun dönemli öğrenme ve tecrübeye atıf yapmış; yönetsel karar vermede sezginin rolünü, Dewey'in pragmatizmine dayanarak ve Pareto'nun öğretileriyle bütünleştirerek ifade etmiştir. Bu noktada, yönetsel karar verme sürecinde, yöneticilerin mantıksal ve sezgisel karar verme deneyimleri ve yetersiz bilgi durumlarıyla yüzleşme yetenekleri ile bilginin, becerinin, hissin ve ayırt etme gücünün önemini vurgulayan Simon'un görüşlerini de gözden kaçırmamıştır. Yine Barnard'ın sınırlı tercih hakkı, Simon'un (1987) ise sınırlı rasyonalite olarak nitelendirdiği, eksik bilgi ve öngörülemezlik durumları da söz konusu süreçte etkili olmaktadır. Ayrıca fiziksel sistemin korunması ve sürekliliği çevreye uyum sağlamayı da gerektirmektedir. Çünkü teknoloji ve standardizasyon sonucunda örgüt aşırı bir büyüklüğe ulaşabilmektedir. Bu da örgütün esneklik ve uyum yeteneğini azaltarak etkinliği düşürmektedir. Tüm bunlara ek olarak, yöneticilerin örgütte kabul görebilmek için kişisel zayıflıklarının farkında olarak kendilerini geliştirmeleri ile iletişim ve liderlik becerilerini kullanmalarının gerekliliğinden bahsetmiştir. Karmaşık örgütlerin yöneticileri; teknik, sosyal ve işbirliği becerilerine sahip olmalıdırlar. Teknik beceriler, teknoloji ve örgütün bütünleştirilmesi ile ilgilidir. Sosyal beceriler, çalışanların motivasyonu için gerekli iklimin yaratılmasını kapsamaktadır. İşbirliği becerileri, örgütsel ve bireysel amaçlar arasında denge sağlar. Bu üç beceri, işbirliği sisteminin gelişmesinin temel kaynaklarıdır. Entelektüel kapasite; ikna sürecinde, bireyleri ve grup dinamiğini anlamada, dış çevreyi algılamada ve dış çevreye uyum sağlamada önem taşımaktadır. Ancak abartılmış bir entelektüellik de pek fazla istenen bir durum değildir. Çünkü, grup ile lideri birbirine yabancılaştırmaktadır (Barnard, 1938; Barnard, 1956; Gehani, 2002; Novicevic, Hench ve Wren, 2002; Pye,1994: 1130).

\section{Barnard'ın Görüşlerinin Diğer Yönetim Düşünürlerinin Görüşleri ile Karşılaştırılması}

Söylemleri değerlendirilirken yaşadığı dönemin karakteristiklerinin gözden kaçırılmaması ve sürekli güncellenmesi gereken Barnard'ın uygulamadan gelmesi, mikro bazda ve doğrudan örgüt üzerinden görüş bildirmesi onu diğer dönemdaşlarından (Taylor, Fayol, Urwick, Gulick, Mooney, Reiley vb.) farkı kılmaktadır. Sadece manevi değerlere ve grup kavramına atıf yapmakla kalmayıp temelinde ekonomik ilişkiler yatan etkinlik ve etkililik analizinden de söz etmiş olmasının Barnard'ı kenara itilmekten kurtardığı söylenebilir. Klasik ekol gibi yönetim işinin etkin ve etkili olması üzerine odaklanan Barnard'a göre, etkinlik ve etkililikte klasik yaklaşımın aksine, başlangıç noktası çalışan değil yöneticidir. Yani klasik yönetim düşüncesinin eksik bıraktığı noktaları tamamlayan, Fayol kadar güçlü bir yönetim bakış açısına sahip olan ve Weber kadar da elitist olan Barnard'ın daha ahlaki standartlar belirlediği, daha yumuşak ve insancıl bir anlayışa sahip olduğu ifade edilebilir. Bu noktada, Barnard'ın etkilediği ve etkilendiği sosyal düşünürler; Henderson, Schumpeter, Whithead, Polanyi, Roethlisberger, Simon, Hayek, Pareto, Koffka, Boulding, Brinton, Parsons ve Mayo gibi isimlerdir (Barnard, 1938; Barnard, 1956; Novicevic vd., 2002: 992; Parayitam vd., 2002: 1003).

"Bilimsel yönetimin babası" olarak nitelendirilen Taylor, fabrika seviyesinde ve mavi yakalı personel bazında odaklanırken; Taylor'un varisi olarak gösterilen Barnard ise, örgüt üzerinde yoğunlaşarak üst yönetim ile beyaz ve mavi yakalı personeller bazında odaklanmıştır. Sistemin sınırları konusunda Taylor, 
mikro yaklaşımda verimlilik ile ilgilenirken; Barnard, makro sosyal sistemi vurgulamıştır. Taylor "önce iş, sonra teşvik" yolunu izlerken, Barnard "önce teşvik, sonra iş" yolunu izlemiştir. Çalışanları makinenin bir dişlisi olarak gören Taylor'un mekanik bakış açısının aksine; çalışanları işbirliği sisteminin bir parçası olarak gören Barnard, örgütteki beşeri unsurun karmaşıklığına odaklanmıştır. Endüstriyel ilişkilerin beşeri boyutunda duygular ve bunların etkileşiminin yer aldığını ifade etmiştir. "insan davranışının psikolojik gücüne" dikkat çekerek, insan davranışının karmaşıklığını yönetmede ve sınırlılıkları ile başa çıkmada psikolojik yaklaşımın gerekliliğinden söz etmiştir. Ayrıca bireye ait olarak bilinen özellikleri örgüte atfetmiştir. Örneğin; Maslow'un İhtiyaçlar Hiyerarşisi'ni fiziksel, biyolojik ve sosyal faktörler bazında örgüte uyarlamış gibi görünmektedir (Barnard, 1938; Barnard, 1956; Parayitam vd., 2002).

Barnard'ın örgüt tanımlaması bir Fayol modeli alternatifidir. Barnard, örgütü formel ve informel yönleriyle dinamik bir sosyal sistem olarak ele almıştır. Hiyerarşik emir-komuta zincirine göre örgütü şekillendiren Fayol, iletişimi bir yönetim fonksiyonu olarak görmemiş; koordinasyonu bir alt fonksiyon olarak ele almıştır. Barnard ise, iletişimi temel yönetim fonksiyonu olarak görmüş; koordinasyonun önemini vurgulamıştır (Barnard, 1938). Taylor ve Fayol, yönetimi teknik bir mesele olarak görmekte iken; Barnard, yönetime bir sanat, bilim ve süreç olarak bakmıştır. Barnard, örgütteki teknik işleyişe katılmakla birlikte; bunun ardındaki sosyal işleyişe de dikkat çekmektedir. Örgütü mekanik bir sistem olarak gören klasik bakış açısına statü sistemleri ile yanıt vermektedir. Örgütte işleyişi ve koordinasyonu kolaylaştıran bu sistemler; ilişkileri, davranış kalıplarını ve normları belirlemektedir. Ancak söz konusu sistemin bireyi yok eden, bireyin özlük ve kişisel haklarına saldıran bir sisteme dönüştürülmesi; patolojik sonuçlar doğurmaktadır. Diğer bir ifadeyle, statülerin kalın çizgilerle birbirinden ayrılması ve statü sembollerinin gereğinden fazla önemsenmesi; uyumun, yaratıcılığın, yeniliğin ve esnekliğin önüne geçilmesine neden olmaktadır. Her ne kadar farklı roller üstlenseler de çalışanların özünde birer insan olduğu gözden kaçırılmamalıdır (Barnard, 1956; Rabin, 1994: 1240).

Barnard, Harvard desteği ile yaptığı Hawthorne Araştırmaları'nda klasik yönetim düşüncesinin zaafiyetlerini gidermeye çalışan Mayo ile aynı amaç doğrultusunda ilerlemektedir (Barnard, 1938; Scott, 1994: 1097). Bir sosyal bilimci olan Follett; takım liderliğinden, demokratik liderden, esnek düşünüp esnek davranılmasından ve katılımcı yönetimden bahsetmiştir. Bir yönetimci olan Barnard ise; ahlak kodları yaratılmasından, yaygınlaştııılmasından ve benimsetilmesinden söz etmiştir. Dolayısıyla yöneticiliğin elit bir sınıf tarafından icra edilebilecek bir meslek olduğunu belirterek, herkesin yönetici olamayacağını vurgulamıştır (Barnard, 1938; Golembiewski ve Kuhnert, 1994: 1228; Üsdiken, 2002: 131).

"Koruma" kavramı, Thompson tarafından "teknik özün muhafazası" anlamında kullanılırken; Barnard tarafından "etkinlik ve etkililik" anlamında örgütün devamlılığının sürdürülmesi için kullanılmıştır (Scott, 1982: 198). Simon; yönetim teorisinin merkezinde, sosyal insan davranışının, rasyonel ve rasyonel olmayan görünüşleri arasındaki kısıtılıkların olduğunu belirtmiştir. Barnard ise, kavramlar arasındaki sınırlılıklar üzerine bir yapı kurmayıp işbirlikçi sistemin sorunlarına bilimsel açıdan yaklaşmanın yönetim sanatı için daha yararlı olacağını düşünmüştür (Pye, 1994: 1130).

\section{Barnard'ın Görüşlerine Yönelik Değerlendirmeler}

Barnard'ın kitabının en büyük zayıflığı; sorumluluk ve yetki devri konusuna yeterince eğilmeyerek, otorite kavramı üzerine yoğunlaşmasıdır. Otoriteyi "türetilmiş bir kurgu" olarak algılayan ve "bir iletişim meselesi" olarak vurgulayan Barnard, pozisyondan ve liderlik özelliğinden kaynaklanan olmak üzere iki tür otorite tanımlamıştır. Perrow’a göre Barnard, örgütü yüceltip bireyi küçültmüştür. Barnard'ın işbirliği anlayışında, çalışanlar pasifize edilmiş gibidir. Yani Barnard'ın çalışanlara yönelik bir bakış açısı yoktur, elitist bir bakış açısı vardır. Barnard'a göre, önemli olan işbirliğinin devamlılığıdır; bireyler sadece örgütün çevresinin birer parçasıdırlar ve enerjilerini kolektif faaliyetler ile örgütün özü için toplamışlardır. Yani Barnard, aslında çok da demokratik değildir; kitapta zaman zaman otoriter bir ses de duyulmaktadır. Ayrıca bazı eleştirmenler de Barnard'ın; cinsiyet, ırk ve etnik köken bakımından ayrımcılık yaparak çıkar gruplarını tanımladığını tartışmaktadırlar. Bu bağlamda, hiç kimse, Barnard’ın ulusa yol göstermek için ahlaki otoriteye sahip olunmasında en iyi yolların özel sektörden geldiğini belirtmesine şaşırmayacaktır. 
Çünkü Barnard, kapitalizmin savunucusu ve bir statükocu olarak algılanabilir. Her ne kadar kitabı basan Harvard, bu durumu "doktrin yazmanın zorluğuna" Barnard ise "metne anlam katılabilmesi için tekrar tekrar okunması gerektiğine" bağlasa da söz konusu kitabın diğer bir zayıf yönü de yazım tarzının anlaşılmasının güç olması ile lisanının modasının geçmiş ve amatör olmasıdır. Barnard'ın anlatım ve yazım dili akademik değildir, yaklaşımı gösterişlidir, somutlama sıkıntısı vardır, örnekleri muğlaktır, tekrarlamaları çoktur. Fakat içeriği kapsamlıdır (Barnard, 1938; Gehani, 2002: 989; Golembiewski ve Kuhnert, 1994: 1214; Parayitam vd., 2002: 1004).

Wolf (1994); işletme yönetimi alanında özel bir lisan ve kesin bir düşünce geliştirmenin zorluğunu vurgulayarak, Barnard'ın bunu denediğini belirtmiştir. Barnard, yönetim toplulukları için paylaşılan anlamlarla terimler yaratarak önemli katkılar sağlamıştır. Iş̧birliği, etkinlik, etkililik, kayıtsızlık bölgesi, otoritenin kabulü gibi kavramsallaştırmaları ile yöneticiler için ortak bir dil yaratmaya çalışmıştır. Mantıksalsezgisel, formel-informel gibi kavramları eşanlı olarak açıklamış ve söz konusu kavramları bütünleştirmiştir. Dolayısıyla bir kavram kargaşasına ya da ikileme yol açmamışırı. Yönetimin sorumluluklarının niteliğini ve kapsamın gözden geçiren ilk isimlerden biri olan Barnard, ayrıca yönetsel karar verme analizinin babalarındandır ve stratejik yönetim teorisine de önemli katkılar sağlamıştır. Bütün bir örgüt kuramı inşa etmesi, iyi bir örgüt tanımlaması yapması, kitabın herkese (karar kuramcıları, örgüt tarihi araştırmacıları, uygulamacılar vb.) yönelik olması, örgütte işbirliğinin anlaşılmasına yönelik bir bakış açısı sergilemesi, tutarlılığı, ikna edici ve net duruşu bu kitabın üstün yönleri arasında sayılabilir. Sosyal bilimler yazınında gelişen parça-bütün ilişkisini yönetim sürecine başarıyla birleştiren Barnard, beşeri boyutu dikkate alan söylemleri ile örgütsel davranış alanına katkı sağlamıştır. Barnard'ın teşvik ve otorite teorisi ile mübadele yaklaşımı, davranış bilimleri açısından önemlidir (Barnard, 1938; Gehani, 2002: 989; McMahon ve Carr, 1999: 228; Novicevic vd., 2002: 992; Pye, 1994: 1135; Scott, 1982: 198).

\section{Sonuç}

Chester Irving Barnard'ın; örgütlerin birer işbirliği sistemi olmaları noktasından hareketle ortaya attığı, kendi içinde tutarlı ve bütüncül görüşlerinin, yönetim yazınına önemli katkılar sağladığı yadsınamaz bir gerçektir. Barnard; önce bakış açısının benimsenmesi, sonra da sistemin kurulması aşamasına geçilmesi gerektiğini vurgulamaktadır. Bu bağlamda, Barnard'ın herhangi bir araç geliştirmediği ve sürekli olarak temeller üzerinde durduğu dikkat çekmektedir. Ayrıca Barnard'ın, parça-bütün ilişkisini yönetim sürecine başarılı bir biçimde entegre ettiği görülmektedir. Ancak bu noktada, bütünün parçalarını anlamaya çalışarak bütüne bakmanın ne kadar holistik olduğu sorusu akla gelmektedir. Barnard'ın yaklaşımı ile ilgili diğer bir soru da astları önemsiyormuş gibi duran, ancak yönetim adına iş yapan, yani bireyi ihmal eden bir yaklaşımla demokrasi tanımının nasıl yapılabileceğine ilişkindir. Ayrıca motivasyon için ikna ve teşvik yöntemlerinden yararlanılması gerektiği vurgusunun altında ne denli dayatma, telkin ve itaat kültürünün yattığı da merak konusu olabilmektedir. Diğer bir tartışma konusu ise, sorumluluk ve yetki devrine yeterince eğilmeyerek; otorite kavramı üzerinde durulmasının, yönetimin elit bir iş olarak algılanmasından kaynaklanıp kaynaklanmadığıdır. Yetkinin kullanılmasından etkilenen kimseyi de dikkate alan bir yetki görüşüne sahip olunmasının yanı sıra; ahlak kodlarının yerleştirilerek, kayıtsızlık bölgesinin genişletilmesi; dolayısıyla da yöneticilerin işlerinin kolaylaştırılması ve örgütte etkinlik ve etkililik sağlanmasının ne derece ilişkili olduğu da başka bir sorunsaldır. Pozitivizmi eleştirerek, sosyal bilimlerde laboratuvar deneylerinin felsefi yönünün sorgulanmasını akla getiren bir düşüncenin, AT\&T ve Harvard desteği ile hareket etmesi de diğer bir ikilemdir. Bu bağlamda, Barnard'ın görüşlerinin, eleştirel bir bakış açısıyla tekrar gözden geçirilerek güncellenebileceği düşünülmektedir.

Ayrıca Barnard'ın yönetim tarihindeki izlerinin takibi, günümüz istihdam ilişkilerinin karmaşık dinamiklerinin anlaşılması ve endüstri ilişkileri, örgütsel davranış ve insan kaynakları yönetimi alanlarına temel sağlaması açısından da önem taşımaktadır. Örneğin; Barnard'ın birey ve örgüt ayrımı kökenine dayanan işbirliği sistemi kavramsallaştırması, günümüz örgütleri için kolektif bir işbirliğinin tesisi adına çaIışana yönelik bireysel düzeydeki samimi bir yönetsel ilginin kaçınılmaz olduğuna işaret etmektedir. Böyle bir bakış açısıyla organizasyonel başarı, yöneticilerin çalışanların güvenini kazanmalarına ve işbirliği 
yapma isteklerini geliştirmelerine bağıı hâle gelmektedir. Diğer bir ifadeyle, çalışanların tatmini ve motivasyonu üzerinde yönetici davranışları ile örgütsel politika ve uygulamaların kritik bir öneme sahip olduğu; örgütün amaçlarının gerçekleştirilmesinde, çalışana birey olarak odaklanan çağdaş yaklaşımların etkili olacağı vurgusu öne çıkmaktadır. Bu bağlamda, günümüz örgütlerinin çatışma, müzakere, güven, liderlik ve motivasyon gibi olguları Barnard'ın katkıları çerçevesinde ele almaları; çalışan odağını gözden kaçırmamalarını sağlayacaktır. İşverenler ve çalışanlar arasındaki çıkar farklıı̆̆̆ı ve güç dengesizliği temelindeki istihdam ilişkileri kapsamında, çalışanlar açısından güvene dayalı işbirliğini teşvik edecek örgütsel politika ve uygulamaların açığa çıkarılması da derinlemesine araştııılması gereken bir konu olarak durmaktadır.

\section{Araştırma ve Yayın Etiği Beyanı}

Bu araştırma, Etik Kurul izni gerektirmemektedir.

\section{Destek Beyanı}

Çalışmamıza yön verici katkılarından dolayı Sayın Hocamız Prof. Dr. Ferda ERDEM'e teşekkür ederiz.

\section{Çıkar Beyanı}

Makalenin yazarları arasında herhangi bir çıkar çatışması bulunmamaktadır.

\section{Yazarların Makaleye Katkı Oranları}

Makaleye 1. Yazar (\%50), 2. Yazar (\%50) oranında katkı sunmuştur.

\section{Kaynaklar}

Abrahamson, E. (1997). The emergence and prevalence of employee management rhetorics: The effects of long waves, labor unions, and turnover, 1875 to 1992. Academy of Management Journal, 40(3), 491-533.

Barnard, C. I. (1938). The functions of the executive. Cambridge: Harvard University Press.

Barnard, C. I. (1956). Organization and management: Selected papers. Cambridge: Harvard University Press.

Dunphy, S. M. ve Hoopes, J. (2002). Chester Barnard: Member of the 'elite'? Management Decision, 40(10), 1024-1028.

Gabor, A. (2000). The capitalist philosophers: The geniuses of modern business - Their lives, times and ideas. U.S.A.: Crown Publishing Group.

Gehani, R. R. (2002). Chester Barnard's 'executive' and the knowledge-based firm. Management Decision, 40(10), 980-991.

Golembiewski, R. T. ve Kuhnert, K. W. (1994). Barnard on authority and zone of indifference: Toward perspectives on the decline of managerialism. International Journal of Public Administration, 17(6), 1195-1238.

Mahoney, J. T. (2002). The relevance of Chester I. Barnard's teachings to contemporary management education: Communicating the aesthetics of management. International Journal of Organization Theory and Behavior, 5(1-2), 159-172.

Malcolm, S. B. ve Hartley, N. T. (2010). Chester Barnard's moral persuasion, authenticity, and trust: Foundations for leadership. Journal of Management History, 16(4), 454-467. 
McMahon, D. ve Carr, J. C. (1999). The contributions of Chester Barnard to strategic management theory. Journal of Management History, 5(5), 228-240.

Novicevic, M. M., Hench, T. J. ve Wren, D. A. (2002). 'Playing by ear'...'In an incessant din of reasons': Chester Barnard and the history of intuition in management thought. Management Decision, 40(10), 992-1002.

Parayitam, S., White, M. A. ve Hough, J. R. (2002). Juxtaposition of Chester I. Barnard and Frederick W. Taylor: Forerunners of management. Management Decision, 40(10), 1003-1012.

Pye, A. (1994). Walking and talking Chester I. Barnard. International Journal of Public Administration, 17(6), 1125-1156.

Rabin, J. (1994). Barnard and morality in organizations. International Journal of Public Administration, 17(6), 1239-1297.

Resource Business Thinking. (2003). Chester Barnard: Modern man of his time. Business Strategy Review, 14(2), 73.

Scott, W. G. (1982). Barnard on the nature of elitist responsibility. Public Administration Review, 42(3), 197-201.

Scott, W. G. (1994). Chester I. Barnard and other antecedents of the present managerial order. International Journal of Public Administration, 17(6), 1093-1105.

Simon, H. A. (1947). Administrative behavior: A study of decision-making processes in administrative organization. New York: Macmillan.

Simon, H. A. (1987). Making management decisions: The role of intuition and emotion. The Academy of Management Executive, 1(1), 57-64.

Smith, E. B. (1994). Chester Barnard's concept of responsibility. International Journal of Public Administration, 17(6), 1157-1174.

Üsdiken, B. (2002). Tarihsel bir yaklaşımla bilim-yönetim birlikteliği. Yönetim Araştırmaları Dergisi, 2(2), 127-154.

Walsh, A. ve Brady, M. (2019). Chester Barnard revisited: Spontaneous orders and the firm. Journal of Institutional Economics, 15(6), 951-962.

Wolf, W. B. (1994). Understanding Chester I. Barnard. International Journal of Public Administration, 17(6), 1035-1069. 